\title{
THE IMPACT OF CONTEMPORARY ENVIRONMENTAL MIGRATIONS ON INTERNATIONAL SECURITY
}

\section{THE CONSEQUENCES OF ENVIRONMENTAL MIGRATIONS}

From prehistoric times to modern day, large-scale human displacements have always been an important and recurrent share of human activity. They were caused by divers reasons: territorial wars, colonization processes, fleeing persecution or seeking economic welfare. Regardless of the cause of a particular migration, usually the consequences for individuals, states and for the international system are the same.

Unarguably, those who suffer most from the occurrence of environmental migrations, are the individual migrants themselves. Forced to leave behind their lives, because the environment around them is no longer hospitable, they have to seek security in distant, often unfamiliar locations. Typically, they arrive at the destination with empty hands - having most of their belongings lost or damaged in a natural disaster. In order to meet their basic needs, they have to compete with local residents in the labour market. In most cases, due to their unresolved legal status, they cannot work legally; hence, they become a burden for the social services or chose to work illegally. In some states with limited access to the most vital resources (water and food) the newcomers are considered by the locals as a threat to their survival.

From a legal perspective, the lack of effective international regulations regarding the status and the rights of environmental migrants is a reprehensible neglect. As a result, this vast group of people remains beyond the scope of international legislation and therefore lacks indispensable protection. This problem is not so much noticeable in the case of internally displaced persons (IDPs), who continue to live in their country of origin and remain under its jurisdiction. Although the effectiveness of the protection provided for the IDPs in some developing countries can sometimes be questionable, it is clear that third states and international organizations are not responsible for these people. The problem becomes more complicated in cases of international environmental refugees - no longer under the protection of their country of origin, they are also usually neglected by the country of destination.

Mass human displacements pose a threat for the stability of states and thus the whole international security system. Some countries, such as small island states, will soon have to face the very likely necessity to evacuate their entire populations, due to the deteriorating environment. At present, this tragic fate concerns mostly states with rather small populations, e.g. Kiribati, Tuvalu, Maldives, Vanuatu or some of the islands located near the Alaska's shoreline (Kodiak, Aleutian Islands). But the phenome- 
non is also starting to affect some densely populated countries, such as Bangladesh, with $75 \%$ of its land regularly affected by floods. Moreover, the issue is pressing, as it can suddenly be aggravated by additional unforeseeable natural disasters, such as volcanic eruptions, tsunamis or earthquakes (Kelman, 2008).

\section{CONSEQUENCES FOR INDIVIDUALS: MIGRANTS OR REFUGEES?}

Unarguably, the international community has a moral obligation to provide help and assistance to those forced to migrate due to the deterioration of environment. Global warming and the resulting climate change in all continents are unstoppable; therefore the need to find a new home for all environmental migrants is just a question of time. For political, legal and social reasons, it is extremely important to regulate the status of the eco-migrants and provide them with the legal protection and legal frames for their functioning in the new reality. First and foremost, it is necessary to find a universally accepted name and an appropriate definition of the phenomenon. Sadly, despite the alarming scale of climate migrations and the awareness of the potential effects they might have on security, the international community has not yet come to a consensus regarding the formulation of basic terms and definitions. In press releases and academic publications treating this problem, different terms are used with regard to the affected people: environmental migrant, forced environmental migrant, climate refugee, climate change refugee, environmentally displaced person, disaster refugee, eco-refugee or ecologically displaced person. Some believe that these terms are not appropriate, and in order to better grasp the essence of the problem they come up with completely new categories, e.g. climigrant. The choice of one specific term is extremely consequential, as it will entail a certain treatment under the international law and under national legal systems.

Historically, several attempts have been made to define the concept of environmental migrants. The first formal definition of the term is often credited to Essam El-Hinnawi, who in a paper written for the United Nations Environment Programme in 1985 described the environmental migrants as: "people who have been forced to leave their traditional habitat, temporarily or permanently, because of a marked environmental disruption that has jeopardised their existence and/or seriously affected the quality of their life." This definition clearly explains the essence of the problem, however, regrettably, it does not raise the issue of cross-border movements (Myers, Kent, 1995).

Another attempt to define the environmental migrants was made in 1988, by Jodi Jacobson of the Worldwatch Institute. She divided the affected in three groups: "1) those people temporarily displaced due to local environmental disruption; 2) those who migrate because environmental degradation has undermined their livelihood or poses unacceptable risks to health; 3 ) those who resettle because land degradation has resulted in desertification or because of other permanent changes in habitat" (Myers, Kent, 1995). Sadly, this definition lacks several important elements. It does not mention the possibility of cross-border migration, does not refer to the time frames of the migration and finally, it lacks to mention the forced, compulsory character of this migration. 
Another definition often referred to is the one proposed in 1993 by Norman Myers of Oxford University: environmental migrants are "people who can no longer gain a secure livelihood in their homelands because of drought, soil erosion, desertification or other environmental problems, and hence are obliged to move elsewhere, however hazardous the effort" (Myers, Kent, 1995).

These exemplary definitions show how divergent the thinking about climate migration can be. Although each of them emphasizes a different aspect of the phenomenon, all can be considered as correct. However, none of them seem complete and comprehensive. Undoubtedly a relatively little interest in the topic was an additional obstacle in the way to create a universally accepted definition. While paying a lot of attention to the improvement of the situation of political refugees, the international community completely neglected those struck by environmental disasters. This has only changed over the past 10 years, when it became clear that with time the problem will only grow in size and efforts must be made in order to find viable solutions.

Currently, the two most widespread terms used with regard to those affected by the phenomenon of environmental migrations are migrant and refugee. Each of these terms entails a different set of important legal and social consequences, so it is advisable to use them consciously and deliberately. Regarding the formulation of a working definition, the International Organization for Migration (IOM) has proposed the following: "environmental migrants are persons or groups of persons who, for compelling reasons of sudden or progressive changes in the environment that adversely affect their lives or living conditions, are obliged to leave their habitual homes, or choose to do so, either temporarily or permanently, and who move either within their country or abroad" (IOM Discussion Note). Announced for the first time in 2007 during the $94^{\text {th }}$ session of the Council of the IOM, this definition seems quite comprehensive, as it refers to people migrating due to natural disasters, as well as, those migrating due to the gradually deteriorating climate (Brown, 2008). Moreover, it embraces both permanent and temporary migration of either national or international reach. The authors of this definition made it clear that their goal was not to ignore other - social, political or economic - causes of migration, but to emphasize the environmental aspect, which has so far been neglected. Bridging this gap should be the first priority, as most classical theories on migration tend to disregard the environment as a driver of migration. They also underlined the intentional use of the term migrants instead of refugees. The latter has a legal definition, providing a list of circumstances, in which a person can be granted refugee status, environmentally induced threat being excluded from that list. The alternating use of the two names has recently been criticized, as each of them entails quite a different set of legal consequences, as well as, either positive or negative sensations.

Undoubtedly, one important reason standing behind the use of the term refugee is its stereotyped positive understanding. This word is normally associated with a person considered as an undeserved victim of persecution in his country of origin. The need to provide refugees legal and factual protection has never been contested. Meanwhile, the term migrant (and immigrant even more so) has a pejorative repercussion, resulting from the reluctance of many societies towards inflow of foreigners. Immigrants face language and cultural barriers, as well as, legal obstacles to their living and working in a foreign country. In many cities, where the assimilation of immigrants is inhibited, na- 
tional and ethnic minorities' enclaves appear, leading to further deepening of the social divisions and reciprocal aversion. Nevertheless, the extension of the use of the term refugee to all environmental migrants is currently not possible due to the wording of the existing legal definition. According to the Convention relating to the Status of Refugees, a refugee is a "person who, owing to a well-founded fear of being persecuted for reasons of race, religion, nationality, membership of a particular social group, or political opinion, is outside the country of his nationality, and is unable to or, owing to such fear, is unwilling to avail himself of the protection of that country." One can easily point out several elements of this definition, which prevent its use in relation to climate migrants. First and foremost, environmental migrants do not fear of being persecuted for any reason, but leave their homeland because of changes in the ecosystem. Secondly, the term refugee can only be used with regard to those who have left their country of nationality or habitual residence. Meanwhile, most climate migrants chose to move within their country of origin, which is usually linked to limited economic capacities, legal obstacles and a feeling of national belonging. Only if this is not possible, due to an overwhelming area of the country being subject to climate change, they decide to cross borders. Finally, the above-mentioned definition implies that, as soon as the persecution stops, people granted refugee status would most probably return to their country of origin. The refugee status is therefore perceived as a temporary condition. In contrast, it is estimated that a majority of current and future climate migrants will not be able to return to their homeland, because of permanent and irreversible changes in the environment. Rising mean sea level, desertification, deforestation, soil degradation, lack of fresh water - such extreme manifestations of climate change prevent the use of the land for human settlement in the future. Knowing these discrepancies, it is clear that the definition of the term refugee would need to be significantly changed, in order to cover the eco-migrants. This would also result in a serious increase in the number of refugees enjoying protection under the Convention relating to the Status of Refugees. The parties to this convention are obliged to protect refugees staying in their territory, and are therefore not very eager to extend the definition.

Figures from 2013 show that the number of refugees of concern to the United Nations High Commissioner for Refugees (UNHCR) stood at 10.4 million people. A further 4.8 million registered refugees receive assistance in 60 refugee camps in the Middle East under United Nations Relief and Works Agency for Palestine Refugees in the Near East (UNRWA). To this number one should add an estimated 28.8 million internally displaced persons around the world (UNHCR webpage). This last group, although theoretically not covered by the mandate of the UNHCR, has in practise for years been provided limited international assistance. If the international community agreed to amend the current definition of a refugee in order to include the environmental migrants within its scope, the number of refugees of concern to UNHCR would triple from one day to another and could increase even twentyfold by 2050. Given how extremely complicated the work of the UNHCR is today, it seems unimaginable that effective assistance could be provided to such an immense group of people spread around the world. Thus, the reluctance of the international community towards using the term refugee in this particular case does not come as a surprise. 
Clearly, there are well-motivated arguments against the use of the name refugee with regard to environmental migrants. However, given the often-negative connotation associated with the term immigrant, this choice does not seem perfect either. The fact that this particular discussion over the naming of the phenomenon has been on-going for decades shows how delicate and complex this topic is (Brown, 2008).

The lack of a universally accepted name and definition is not only a terminological deficiency, but also a serious obstacle on the way towards creating frames for protection of environmental migrants within the public international law. As a result, the expanding group of affected by the phenomenon is invisible from a legal perspective. There is no institution or organisation, which could officially represent the climate migrants and their interests. No longer under the jurisdiction of the government of their country of origin, lacking legal status in the country of residence and excluded from the scope of interest of international organisations, environmental migrants fall into a legal gap.

Although the definition proposed by the International Organisation for Migration is the most widely used and accepted, there are others worth mentioning. The Climate Institute defines environmental migrants as "people fleeing from environmental crises, whether natural or anthropogenic events, and whether short or long term." The reasons for displacement include: droughts, desertification, deforestation, soil erosion and degradation, scarcity of natural resources, natural disasters and many others including unsustainable human practices, such as over-cultivation. The existing environmental problems are reinforced by poverty, famine, disease and population pressures, as well as, faulty national and international political and legal systems (Myers, Kent, 1995). In some cases concrete incidents (such as dam construction or industrial disaster) become triggers for waves of environmental migration. The Climate Institute agrees that there is a big variety of different overlapping causes, which might lead to climate migration. The organisation seems to leave space for further development of this definition and potential inclusion of new causes.

It is worthwhile to mention one more definition of environmental migrants, proposed in the Report EACH-FOR Environmental Change and Forced Migration Scenarios. This document summarised the findings of a two-year long research project of the European Commission and used a classification of eco-migrants in the following three groups:

1) environmental migrants - people, who voluntarily decide to change residence mainly due to concerns related to the environment;

2) environmental displaced - people forced to leave their habitual residence, because their lives, livelihoods and well-being are threatened by adverse natural events and processes (dependent or not from human activity); and

3) development displaced - people, who are resettled as a result of changes in the land use planning (Jäger, 2009).

This is an atypical and very broad way of defining the group of people concerned by the phenomenon. Most researchers would only agree for the second group of people to be considered as environmental migrants, leaving aside voluntary migrants and resettled people. However, it is important to realize that some international institutions, in this case the European Commission, do allow a much broader understanding of the problem. 


\section{CONSEQUENCES FOR STATES: EMIGRATION OR EVACUATION?}

In most states migratory movements are a natural, widely spread, adaptive mechanism and demographic process, responding to changing conditions and dependent on a number of factors. Only when the size of either the immigration to or emigration from a given state is alarming, does the phenomenon become a serious problem. All the more, it is difficult to imagine that such a problem could affect a whole nation and entail the need to evacuate all citizens. Unfortunately, some island states, whose average height above sea level does not exceed a few metres, should consider such a scenario. According to the Intergovernmental Panel on Climate Change rising seawaters threaten to entirely and permanently flood some islands, destroy the infrastructure on others and completely cut off their access to fresh water. The first mass evacuations have already taken place. 2600 inhabitants of the Carteret Islands, which belong to Papua New Guinea and rise barely 1,5 metres above sea level, were forced to leave the islands. Since 1980s several relocation procedures to the nearby Bougainville Island have been implemented, resulting in the citizens of Carteret Islands being described as the first climate change refugees (UNESCO webpage). Sadly, many more will soon have to share their fate.

The Republic of Kiribati is a state located in the Pacific Ocean and composed of one island and 32 atolls, with a population of 100,000 inhabitants (Loughry, McAdam, 2008). Rising less then 3 metres above sea level, the islands' soil is very infertile. The country is known to the international community as one of the world's most vulnerable to the effects of climate change. This vulnerability is due to the unfortunate environmental conditions, as well as, the limited financial capacities of the citizens and the government. In 2004 the people of Kiribati adopted the declaration Otin Taai, in which they stated that the partly anthropogenic climate change will have an extensive negative impact on the inhabitants of the Pacific Islands including:

- "loss of coastal land and infrastructure due to erosion, inundation and storm surges;

- increase in frequency and severity of cyclones with risks to human life, health, homes and communities;

- loss of coral reefs with implications for the sea eco-systems on which the livelihood of many Islanders depends;

- changes in rainfall patterns with increased droughts in some areas and more rainfall with flooding in other areas;

- threats to drinkable water due to changes in rainfall, sea-level rise and inundation;

- loss of sugarcane, yams, taro and cassava due to temperature extremes and rainfall changes;

- human health impacts with an increase in incidence of dengue fever and diarrhea."

It is worthwhile mentioning that forced migration due to deterioration of the nature is not a novelty for the people of Kiribati. In 1940s increased production of phosphate on Banaba Island left its mark on the ecosystem and forced most of the population to migrate to the Rabi In Fiji Island. Also, a constant flow of people to South Tarawa has been observed over the decades until it was estimated that more than half of Kiribati's population lived on that single atoll. Eventually, the population density was so high, that the government was forced to relocate around 5000 people to the neighbouring atolls (Loughry, McAdam, 2008). 
In 2005, during the 60th session of the UN General Assembly, the President of Kiribati Anote Tong, reported the need to seriously consider the possibility of relocating the state's 100000 population, as a result of climate change (Loughry, McAdam, 2008). Arguing that it might be too late to look for other measures, President Tong said that the international community should face up to the fact that an evacuation is the only feasible solution. He also underlined the economic dimension of migration - working and consuming abroad the Kiribati people would on the one hand contribute to local economic growth, and on the other hand, be able to provide financial support to those family members remaining on the islands. The message was addressed primarily to the representatives of the governments of the neighbouring Australia and New Zealand. Meanwhile, in September 2007, the Pacific Conference of Churches, called on member churches to show compassion and provide help to the people of Kiribati, Tuvalu and the Marshall Islands, who wish to settle in other countries of the region. It was also proposed that a regional migration policy could be established, in order to enable those affected by climate change to settle in selected continental or island states in the region.

The use of the notion of evacuation with regard to environmental migration seems to be supported by one more argument. Many visible effects of global warming and climate change are natural disasters. They pose a direct and immediate threat to human life and health, as well as to infrastructure, such as housing. Putting people in extreme situation, these violent cataclysms leave behind fatalities and wounded. The evacuation of Japanese people living around the nuclear power plants Fukushima I and II is a perfect example. The reaction of the authorities was immediate: during the first two days after the earthquake and the hydrogen explosion, which took place on 11 March 2011, 140,000 people living within a $20 \mathrm{~km}$ zone around the power plant were evacuated. International institutions have recognized the risk of similar occurrences happening in the future. In 2006 the World Bank has published a report under a suggestive title Not If But When? The document speaks of the inevitability of climate change and the need to find solutions for entire states and nations at risk.

\section{SUPRANATIONAL CONSEQUENCES - THE RISK OF INTERNATIONAL CONFLICTS RESULTING FROM ENVIRONMENTAL MIGRATION}

Human knowledge about how exactly climate change will progress in the following years is rather scarce. This makes it very difficult to predict the prospective effects of environmental migrations on individual countries and on the relations between them. Global warming is of course a scientifically measurable phenomenon, but the theoretical forecasts differ so much between each other, that there can be no certainty as to the hypotheses. The existence of specific parameters, which allow determining the degree of the already accomplished and the potential changes, is very helpful. These parameters include among others: the average global temperature, the carbon dioxide concentration in the atmosphere, the Earth's ice cap surface, mean sea level, or the frequency of extreme natural disasters. Any slightest variations in these parameters are associated with weighty consequences for the entire environment, for individual climate zones and for people around the world. 
The degree/extent to which a certain state or society succumbs to climate change can be defined by two notions introduced to the study of international relations by Robert Keohane and Joseph Nye in late 1970s. These two terms are sensitivity and vulnerability (Keohane, Nye, 1977). The first one can be defined, after John Houghton, as the degree, to which a system - be it ecological or social - changes due to climate change (Houghton, 2009). As to vulnerability, it should be understood as the extent of the losses made by the ecological or social system as a result of climate change (Leary, 2009). The distinction between ecological and social systems is basically just a formality, as in reality they are closely interrelated and any changes occurring in one affect the other. The ecosystems give place for the social systems to evolve and provide them with all the necessary resources: food, water, energy and any other needed material. For centuries, the adaptive capacities allowed people to get used to any changes occurring within the ecosystems but today the extreme pace of global warming brings about unprecedented changes, significantly hampering human adaptability. The level of sensitivity and vulnerability of individual societies and states will determine their choice of response actions, as well as, their chances to survive. While the sensitivity and vulnerability of diverse ecosystems (deserts, forests, glaciers etc.) can be easily indicated, in case of states it depends on numerous factors: location, stability of political system, financial resources, the existence of innovative technologies or the ability of the government and economic and social systems to adapt (Pietraś, 2011).

This leads to the conclusion that the group of states most vulnerable to climate change is composed of poor, developing countries with unstable governments, as well as those located in most sensitive ecosystems: deserts, islands or coastal areas. A brief analysis of climate change impacts around the world allows indicating the most threatened regions: Africa, Middle East and West Asia are particularly vulnerable to the effects of global warming. Water scarcity and prolonged droughts lead to desertification and visible decrease of food production; rising seawater levels pose a threat to densely populated coastal areas; and, lasting high temperatures favour disease transmissions. The adaptation to changes is all the more difficult because the political systems are often unstable. Due to on-going international conflicts, civil wars and revolutions, North Africa and Middle East are hotspots, where starting a discussion on topics related to global warming very often turns out to be impossible.

Another concept of fundamental importance for the analysis of the effects of climate change and climate migrations for international relations is the securitization. It is the act of declaring, that a certain phenomenon, process or action of another entity is an existential threat (ibidem). In this sense, security is a speech act, resulting in the subject of securitization being included in the group of security threats requiring emergency measures. Although climate change and environmental degradation have been considered as a threat for decades, the relevant act of securitization has been made relatively recently. On 24 October 2006 the British Minister of Foreign Affairs Margaret Beckett stated, during her speech given in Berlin, that "climate change is a serious threat to international security" and that "achieving climate security must be at the core of foreign policy" (Scott, 2008; Trombetta, 2008). This was the first time that the term climate security was used deliberately and with direct reference to foreign policy. However, it 
does not refer to the security of the climate itself, but that of the society living in a particular ecosystem and influenced by all changes and threats occurring within this ecosystem. According to Marek Pietraś such threats fit perfectly in the argumentation accompanying Ulrich Beck's concept of risk society. The keystone of this concept is the assumption that in order to be able to face a new distinctive risk, a modern society must use new and distinctive security policy instruments. Among those modern risks Beck lists: a) changes in the functioning of global economy, b) conflict of interests between the states mostly responsible for climate change and those affected by it, c) possible increase of the number of failing states and those with limited regulatory powers, d) changes in the conditions for exercising human right and assuring people's safety, e) stimulation of integration processes, f) social life destabilization (Pietraś, 2011). Beck underlines that contemporary security policy should be based on instruments aiming to prevent these modern threats.

It is possible to distinguish two types of cause-effect relationships linking climate change to international security. The first one refers to direct negative impact of environmental degradation on human life, health and welfare. The second causality relation treats climate change as a possible motive for starting internal or international conflicts, including armed ones. On this basis, four different types of conflicts resulting from climate change may be distinct. The first group is made by conflicts over the remaining, continuously shrinking natural resources, such as water, food, energy or the inhabitable land. As the most unbearable, water scarcity might be the biggest conflict trigger within this group (Klare, 2007). The second type of conflicts includes those taking place in polar regions, especially the Arctic. According to Dariusz Brodawka, disagreements over the delimitation of the continental shelf and the territorial waters may eventually result in an international conflict (Brodawka, 2009). The third group of conflicts are those resulting from the continued weakening of some states with inefficient governments who are no longer able to control their territory. In a country undergoing political, economic or social perturbations, severe environmental degradation can easily trigger a social rebellion, and the formation of internal or cross-border paramilitary and revolutionary structures (Klare, 2007). Finally, the last group of conflicts involves those based on migration processes. It is undisputed that the escalation of environmental migration will increase the probability of the emergence of new conflicts. There are two groups of states at risk of falling into such a conflict. The first one includes developing countries, which, due to their location, increased sensitivity and vulnerability, will mostly suffer from the negative impact of climate change. The combination of population growth and increases in poverty on the one hand, and extreme natural events, water scarcity or droughts on the other hand, will provoke mass waves of emigration. Most migrants will try to seek shelter in the neighbouring countries, which will suddenly have to face an immense flow of people. These states form the second group of countries particularly vulnerable to migration-induced conflicts. Thus, the majority of potential climate migration induced conflicts will not move beyond certain vulnerable regions: Africa, Middle East and South Asia. Some of them will at first have a limited national scope and will spread to other countries in the region only after some time. The moment of the outbreak is rather difficult to predict, therefore the international community should carefully observe the potential hotspots. 
Clearly, environmentally induced migration would not lead to a conflict single-handedly. Changes in the ecosystem and the resulting movement of people can definitely intensify the existing social, ethnic or political turbulence. But an accumulation of several different problems is usually needed in order to channel a clash. The more overlapping causes of a conflict, the more difficult it is to avoid an escalation of aggression and eventually a confrontation. As already mentioned, the parties to the conflict would first and foremost fight for the access to the existing natural resources. In consequence, this may trigger one of the following two processes: ecological marginalisation or resource capture (Clark, 2008). Both are much more likely to happen in states with unregulated land ownership, where archaic models have not yet been replaced with proper legal standards relating to immovable property or state property.

Ecological marginalization occurs when high population growth rate and uneven access to natural resources force some groups of citizens to migrate to peripheral, less accommodative areas, such as deserts or steep mountain slopes (ibidem). Elevated environmental vulnerability and reduced agricultural suitability of these lands markedly limit the chances of their exploitation. When the government of the Philippines supported the creation of large agricultural farms at the expense of smaller and less profitable ones, many small farmers were left empty-handed. Forced to migrate, they started cultivating land on steep slopes, but it quickly became obvious that this terrain was not suitable for any type of crops. The farmers revolted and an internal conflict encompassed an important part of country's territory, remaining outside the effective control of the government.

Meanwhile, resource capture is a process in which the strong and the weak classes of a society fight between each other for the existing natural resources (ibidem). The construction of several dams along the Senegal River, in Mauritania, Senegal and Mali, was an important and needed investment. It allowed the generation of hydropower, land amelioration and river engineering. At the same time, it also resulted in a very fast increase of land value along the course of the river. The elites swiftly changed the law in order to enable a quick takeover of the valuable land, forcing thousands of people to relocate and limiting the access to the river to an overwhelming part of the society. As a result, over 20,000 Mauritanians emigrated to neighbouring Senegal, from where they continue to attack their former lands in order to recuperate the expropriated cattle.

All the above-mentioned premises of the environmentally induced conflicts are present in countries in Africa, Middle East and to a lesser extent in Asia and South America. "Twenty-five countries - of which the majority are in Africa - have been identified as falling in the highest risk category of civil conflict in the next two decades, and the likelihood continues to increase over time. All these countries have low cropland availability per person, half of them have fresh water availability problems and all are ranked amongst the poorest nations in the world."

\section{THE PROGNOSIS REGARDING ENVIRONMENTAL MIGRATIONS}

Disposing of the knowledge on former climate migrations, and of precise data on contemporary environmentally induced human movements around the globe, climatologists attempt to anticipate the future development of this phenomenon. They offer 
complex scenarios, which comprise: specific predictions regarding the further progress of climate change in different parts of the world; the proposals for action needed to stop the climate change; the approximate number of future climate refugees; and recommendations on the actions which could alleviate the problem and lower the scale of the climate migrations.

In his scenario for the year 2025 Norman Myers has presented a pessimistic vision of both the environment and the fate of millions of people living in the regions most threatened by natural degradation (Myers, Kent, 1995). The scientist does not undertake to provide a specific number of people who, in his opinion, may become climate migrants, because he believes that the multiplicity of conditions and variables reduces the credibility of such estimations. Instead, in a relatively precise way, he analyses those factors having most impact on the lives of people and their decision to emigrate. According to the report prepared by Myers for the Climate Institute, further continuation of the destructive and unrestricted rainforests logging will lead to a rapid increase in greenhouse gas emissions, violation of water cycle and soil degradation. The acceleration of global warming will cause further desertification of areas inhabited by as many as 225 million people. Even more will suffer from water scarcity - their numbers could reach 3 billion people. The complete lack of water will threaten a number of countries including Libya, Kenya, Rwanda, Somalia, Tunisia, Algeria, Burundi, Malawi and Morocco. Meanwhile, Egypt, Nigeria, Ethiopia, Tanzania, Zimbabwe, the Republic of South Africa, Haiti and parts of China, India, Pakistan and Mexico will join the list of territories suffering from a chronic lack of water (Myers, Kent, 1995). In addition, natural disasters resulting from climate warming will proliferate. Increased rainfall in tropical and subtropical forests, more frequent and more severe cyclones, prolonged droughts, and heavier flooding - these phenomena will be the direct effects of changes in the monsoon season. According to Myers, the rise in global average temperature of just $1{ }^{\circ} \mathrm{C}$ can visibly impair the existing cycle of summer and winter monsoons, which has a decisive influence on the climate of Central America and southern and eastern shores of Asia. Climate change will be accompanied by an exceptionally rapid population growth, particularly in developing countries. India, China, Egypt, Mexico and sub-Saharan Africa might face a 55\% increase in population compared to 1995 . This means that even with a moderate population growth in other countries, the final number of the world's population in 2025 may reach 8.3 billion (Myers, Kent, 1995). What is more, Myers estimates that up to 5 billion people will inhabit coastal areas, which are the most vulnerable to permanent inundation by rising seawaters, and being struck by cyclones and tsunamis. The simultaneous population growth and ecumene ${ }^{1}$ shrinkage will ultimately lead to people competing for land and for the diminishing natural resources. As environmental migration becomes a widely used adaptive method, the resulting influx of people to cities will trigger the effect of urban explosion. In search of work and better living conditions, people will settle on the outskirts of big cities, provoking further extension of slums and favelas. The extreme poverty and alienation of immigrants living in such slums will be multiplied by an inefficient urban infrastructure.

1 The term ecumene originally comes from the greek oikoumene, which refers to the inhabited universe (Kaczmarek, 1998). 
In most reports, one of the key recommendations is to conduct the most sustainable economy leading to sustainable development. The protection of natural resources together with the proper land and water management are the basis of green politics. States should encourage small and large businesses to introduce eco-friendly innovations. They should also seek to resume the functioning of local traditional industries. Adequate incentives should be introduced in order to convince farmers to create self-sufficient environmentally friendly farms. Moreover, it is essential to take action against illegal logging, sewage disposal and soil contamination. However, these measures can only alleviate the situation, but cannot stop climate change altogether. For this reason it is equally crucial to adapt to the changing circumstances. Global warming and the related environmental changes already affect the lives of various human communities throughout the world. The adaptive strategies laid down by individual states should consider the local characteristics of the problem, the traditional adaptive methods used in past by local population and the speed of the on-going changes. In addition to preparing national adaptive strategies, governments ought to allot financial resources for early warning systems and educational programmes. The latter are of crucial importance for raising awareness of the causes and consequences of climate change, reasons standing behind environmental migrations, and the existing methods of environment protection. On a local scale, such educational programmes may contribute to a significant reduction of the negative human impact on the environment. What is more, better knowledge on the phenomenon and exchange of information between communities and governments would enable regional and international cooperation for the promotion of ecological behaviour and remedial actions. Finally, another important recommendation present in all reports and scenarios on environmental migration is a warning against excessive inhibition of migration. Being the most obvious and natural reaction, it partly solves the problem and can stimulate the economic growth, increase the mobility of workers and entail cultural exchange. Human migration is a permanent feature of the contemporary world, in which crossing borders is easier than ever before. Therefore, appropriate supervision of moderate migratory flows is most desirable.

$$
* * *
$$

Unarguably, the processes of human migration are one of the most complex, multi-faceted and intriguing realms of the study of population geography. A preliminary analysis of the subject allows one to realize that there is no one explanation of how those processes work. Compound, multistage and multidirectional, they differ in terms of intensity, scope of time, space and subject. They also tend to be crosscutting: one human movement can give rise to another or split to several migrations, a number of them can merge or only partly intermingle.

Another element, which adds to the overall complexity of human migrations, is the multitude of its causes and results. The range of migration agents - stimulators, regulators and determinants - is as well fairly abundant. Yet, one property, which all migration movements have in common, is the strong correlation with the civilization progress, social system development and climate change. Nowadays, this correlation has brought about a modern type of environmental migration. 
Given how much attention is currently paid to ethnic and religious conflicts, how empathic the international public opinion feels for refugees and national minorities, it seems unbelievable that the situation of environmental migrants is not only not yet regulated but hardly even acknowledged. Meanwhile, the results of studies and research performed by climatologists are alarming and unequivocal: the contemporary world is facing the climate change advancing at an extreme pace, which is faster than any climate shift in the past centuries. The constant rise in global mean temperature entails a multitude of consequences for the Earth's ecosystem. Most of these effects pose direct danger to human life and health, destructing at the same time the infrastructure needed for human survival. As a result, the number of environmental migrants grows proportionally to the progress of the greenhouse effect and the climate change.

The international community should react forthwith. Efforts must be made in order to slow down the pace at which climate-induced migration is growing. Yet this can only be achieved if the right methods are discovered and applied. The key to finding them is hidden in understanding the essence of environmentally induced migration and in anticipating its consequences for international relations.

Paradoxically, environmental migration is a problem, which should concern not only the states suffering the most from climate change, but the entire international community. We live in a closed ecosystem disposing of limited amounts of resources, regrettably mostly non-renewable. Centuries of thoughtless overexploitation and unsustainable use of natural resources have led to inefficiency of the Earth's ecosystem. This malfunction manifests itself in different ways and intensity across all continents. Moreover, the causal nexus may be expanded in time and in space: a particular action in one place can contribute to the deterioration of the natural environment in a very distant location. Therefore, undoubtedly, the negative consequences brought about by climate change will ultimately occur in every corner of the world. Climate migration is a problem of international scope, and can result in civil wars and international conflicts.

Evidently, in the years to come the number of migrants forced to flee from their habitats will sharply increase. The more there are and the longer the international community waits with regulating their status, the bigger the probability of an outbreak of regional and international conflicts. Such conflicts are usually caused by a whole range of overlapping reasons: political, economic, ethnic, religious, social. In this case, the migratory motive related to the shrinking of the ecumene will be the primary one. Most of the environmental migrants are poverty-stricken people from developing countries. They do not dispose of sufficient means for life, not to mention emigrating and installing themselves in a different state. Thus, if possible they remain within the borders of their country of origin (internally displaced people), where they have a feeling of belonging. If the whole territory of a country is threatened, or when the pull factors in foreign states are exceptionally strong, the migration happens on international level. Taking these under consideration and having in mind that the number of environmental migrants will constantly grow, the risk of outbreak of international conflicts rises considerably.

Undoubtedly, more attention should be paid to the difficult situation of small island states, which face the possibility of being forced to evacuate the entire population from its territory. Tuvalu, Kiribati, Vanuatu, Maldives, some of the islands located in the Bay 
of Bengal or near the Alaska's shoreline - these are the first to be lost in the battle with the rising sea level. The on-going melting of the polar ice cap slowly changes the fate of the low-lying states. European and North American governments underestimate the problem, believing that it only affects a few sparsely populated island states. Meanwhile, inevitably, the next to be flooded are: Venice, Manhattan or San Francisco.

The appeals made by the International Organisation for Migration, the Intergovernmental Panel for Climate Change and many other organisations and governments should be heard by the international community. It is high time to recognize the problem on the grounds of international law and start its legal regulation. Universally accepted definitions of environmental migration and climate refugee are indispensable in order to assure international legal protection for those affected by the problem. The timely creation of an effective, institutionalized support mechanism for climate migrants will help avoid the potential migratory induced conflicts. It can also contribute to extensive cooperation between states and governments on an entirely new level.

It is worth to point out, that although the knowledge about the contemporary environmental migrations is still quite limited, it is clearly an interesting and challenging topic to study. Given the complexity of the issue a multidimensional approach is needed. The contemporary climate migrations constitute a problem of global scope, thus being strongly interconnected with domains such as: international politics and security, economics or human rights, not to mention geography and ecology. The interdisciplinary and complex nature of the issue adds to the difficulty of finding a viable solution. Nevertheless, the essence of the problem lies in the fact that it is a growing and long-range phenomenon. The scientific scenarios are all consentaneous: in the near future the problem will grow to unprecedented levels leaving no state or population unaffected.

\section{Bibliography}

Brodawka D. (2009), Zmiany klimatu jako nowe zagrożenie bezpieczeństwa, Warszawa.

Brown O. (2008), Migration and Climate Change, "IOM Migration Research Series", Geneva.

Clark W. A. V. (2008), Social and Political Contexts of Conflict, "Forced Migration Review”, No. 31.

Discussion Note: Migration and the Environment, http://www.iom.org.

Houghton J. (2009), Global Warming: The Complete Briefing, Cambridge.

Jäger J., Frühmann J., Günberger S., Vag A. (2009), Environmental Change and Forced Migration Scenarios Project Synthesis Report.

Kaczmarek T., Koralewski T., Matykowski R. (1998), Wielka Encyklopedia Geografii Świata, tom XII: Ludność Świata, Poznań.

Kelman I. (2008), Island Evacuation, "Forced Migration Review”, No. 31.

Keohane R., Nye J. (1977), Power and Interdependence: World Politics In Transition, Boston.

Klare M. (2007), Global Warming Battlefields: How Climate Change Threatens Security, "Current History".

Leary N. (2009), Climate Change and Vulnerability, London.

Loughry M., McAdam J. (2008), Kiribati - relocation and adaptation, "Forced Migration Review", No. 31 . 
Myers N., Kent J. (1995), Environmental Exodus. An Emergent Crisis in the Global Arena, Project of the Climate Institute, Oxford.

Pietraś M. (2011), Międzynarodowy Reżim Zmian Klimatu, Toruń.

Scott S. (2008), Securitizing Climate Change: International Legal Implications and Obstacles, "Cambridge Review of International Affairs", No. 4, Vol. 21.

Not If but When?, Adapting to natural hazards in the Pacific Islands Region, http://www.worldbank.org.

Trombetta M. J. (2008), Environmental Security and Climate Change: Analyzing The Discourse, "Cambridge Review of International Affairs", No. 4, Vol. 21.

UNESCO webpage, http://www.unesco.org.

UNHCR webpage, http://www.unhcr.org.

\begin{abstract}
The $20^{\text {th }}$ and $21^{\text {st }}$ century is a period of great changes, with the civilization-enhancing digital revolution on the one hand and the emergence of new global threats on the other hand. Unarguably, global warming is among the most serious challenges, bringing about dire consequences for humans, the environment and the international security. One of them is the phenomenon of contemporary environmental migrations, which was until recently marginalized, and today causes deep concerns of the entire international community. The purpose of this article is to characterize the problem of contemporary environmental migrations, present the predictions regarding its further development, and discuss its effects on the individuals affected, states and international relations.
\end{abstract}

\title{
WPLYW WSPÓLCZESNYCH MIGRACJI KLIMATYCZNYCH NA STOSUNKI MIĘDZYNARODOWE
}

\section{STRESZCZENIE}

Przełom XX i XXI wieku to wyjątkowy okres w historii cywilizacji, naznaczony rewolucją techniczną i cybernetyczną, ale także nowymi zagrożeniami i problemami. Niewątpliwie jednym z najpoważniejszych jest żywo dyskutowany efekt cieplarniany oraz jego skutki dla człowieka, środowiska naturalnego oraz bezpieczeństwa międzynarodowego. Problem współczesnych migracji klimatycznych, choć jeszcze niedawno bagatelizowany, dziś budzi niepokój społeczności międzynarodowej. Celem artykułu jest omówienie fenomenu współczesnych migracji klimatycznych, przedstawienie prognoz rozwoju problemu w najbliższych dziesięcioleciach oraz prześledzenie jego następstw dla osób bezpośrednio dotkniętych, państw i dla systemu stosunków międzynarodowych. 
